\title{
The Effect of using Jumble Letters in Teaching Vocabulary in Grade Eight Students of SMP Negeri 7 Pematangsiantar
}

\author{
Pdt. Partohap S.R. Sihombing, S.Th.M. Pd
}

English Department Faculty Teacher Training and Education, Nommensen University Pematangsiantar, Indonesia. Email Id: partohap.sihombing@uhn.ac.id

\begin{abstract}
This thesis is the effect of using jumble letters in teaching vocabulary in grade eight students of SMP Negeri 7 Pematangsiantar. In this thesis, the problem of the study justifies as "Does the use of Jumble Letters affect the students' vocabulary achievement in grade eight students of SMP Negeri 7 Pematangsiantar?'To answer the problem, the writer follows some theories namely: Yule (2010: 117), Agoestyowaty (2007:38), Carten (2007:21), Nunan ( 2005:121), Bruner (1983: 112).This thesis is quantitative descriptive study design, because it is to find the effect of using jumble letters in teaching vocabulary. The subject of this study is the grade VIII students of SMP Negeri 7 Pematangsiantar. VIII 10 which consists 20 students as control group and VIII $I_{8}$ which consists 20 students as experimental group. Total number of sample are 40 students.The objective of this study is to know the effect of using Jumble Letters on the students' vocabulary achievement in grade eight students of SMP Negeri 7 Pematangsiantar. In analyzing, the data shows that the students' vocabulary in grade $\mathrm{VIII}_{8}$ increases significantly. It shows by the improvement of the students' score from the pre - test to post - test. In pre-test of experimental group, it shows that the mean (M) in pre-test is 65,the median is 62.5, the highest score is 75, and the lowest score is 60 . While in post - test of experimental group, it shows that the mean (M) in post - test is 80.25, the median is 80, the highest score is 90, and the lowest score is 70.Based on the calculation of $t$-test, it was found out that $t$-observed is (8.46) and it is higher than t-table (1.66) at the level of significance (0.05). It means that there is a significant effect of using jumble letters in teaching vocabulary in grade eight students of SMP Negeri 7 Pematangsiantar. Since the result of $t$-observed is higher than $t$-table (8.46 > 1.66), the null hypothesis (Ho) is rejected and the alternative hypothesis ( $\mathrm{Ha}$ ) is accepted. It means that there is a significant effect of using jumble letters in teaching
\end{abstract}

vocabulary in grade eight students of SMP Negeri 7 Pematangsiantar. Finally, the writer hopes that the research will help the students' to increase their vocabulary. And the teachers are suggested to apply jumble letters as one of technique to increase the students' vocabulary achievement.

Keywords -Jumble Letters, Teaching Vocabulary, Effect.

\section{INTRODUCTION}

Learning vocabulary is very important part of learning a language. Students learn English in order to enable to communicate in that language. The problem is the teacher's technique used in teaching vocabulary is not interested or monotonous. It makes the students lazy in learning vocabulary and most of the student get low score in vocabulary, actually the main problem is the students get difficulty to memorize a long list of words, usually teachers teach vocabulary by asking students to consult the dictionary, and the bad effect is they usually forget the word.

Carten (2007 : 21) stated that learning vocabulary is largely about remembering and students generally need to see, say, and write newly learn words many times before they can be said to have learned them. From this quotation, the students should review vocabulary that they have studied. Repetition is an important aid to learn and to actively recall words and procedure them rather than merely or hear them. The use of games in learning environment will not only change the dynamic of the class, but it will also rejuvenate students, rejuvenate means that it will make the students easier to learn vocabulary, and help the brain to learn more effectively. The more exciting and interactive the teacher can make the learning environment, the more teacher tries to introduce games and activities, the more a teacher change shape and manipulate both language and environment, the better the circumstance for students. Based on the high 
quality of games the writer tries to apply one part of it that is Jumble Letters in teaching vocabulary. Therefore, the writer interest to make a research with the title "The Effect of Using Jumble Letters in Teaching Vocabulary in Grade $\begin{array}{lllll}\text { Eight Students of SMP NEGERI } 7 & \end{array}$ PEMATANGSIANTAR". The writer hopes that creating activities using Jumble Letters can help the students to improve their vocabulary achievement.

\section{The Problem of the Study}

Based on the background of the study, the writer formulated the problem as "Does the use of Jumble Letters affect the students' vocabulary achievement in grade eight students of SMP Negeri 7 Pematangsiantar?"

\section{The Objective of the Study}

The objective of this study is to know the effect of using Jumble Letters on the students' vocabulary achievement in grade eight students of SMP Negeri 7 Pematangsiantar.

\section{REVIEW OF LITERATURE}

To support the idea of this study, the writer uses some theories to help the writer in completing this study. The writer use theory of Yule (2010: 117) said that synonyms are two or more words with very closely related meanings. Yule (2010: 117) said that antonyms are two forms with opposite meanings. Agoestyowaty (2007:38) said that using of games in a learning environment will not only change the dynamic of the class, but it will also rejuvenate students and help the brain to learn more effectively. Carten (2007:21) said that learning vocabulary is largely about remembering, and students generally need to see, say, and write newly learned words many times before they can be said to have learned them. Nunan (2005:121) said that vocabulary is the collection of words that an individual knows. Bruner (1983: 112) stated that jumble is a word puzzle with a clue, a drawing, ilustrating the clue and a set of word, which is jumbled by permuting its letter to make an anagram. Vocabulary is one of the language aspects which should be learnt. In learning vocabulary automatically we have to know the meaning of words it self and can use it in sentences. Vocabulary is commonly defined as all the words known and used by a particular person. Nunan (2005:121) said that vocabulary is the collection of words that an individual knows. Vocabulary is important in learning English. It means that it would be easier for students to use the language appropriately if they know the word in the language since they know the meaning. Vocabulary usually grows and evolves with age, and serves as a useful and fundamental tool for communication acquiring an extensive vocabulary is one of the largest challenges in learning a foreign language.Vocabulary is language component which contain all of information about meaning and using of words in language which are processed by a speaker, a writer or listener. Furthermore, Hornby (1989:1025) said that, the vocabulary is total number of words which make up a language. According to Lado (1979: 115) said that vocabulary of the first language is learned at home in the great struggle of the child to communicate his needs. He or she learns words from the people with whom they live, for the things they need and for the action he wants performed or stopped. It means that vocabulary is central of language in teaching and learning. When a student studies English, the first thing that he or she should learn is vocabulary.

\section{Types of Vocabulary}

Vocabulary is the one of the basic element in achieving language skills. It is impossible for the students to understand what their teacher explains without knowing many vocabularies.

As stated by Fries (1975:45), vocabulary can be classified into some types, namely:

a) Content Words represent the name of subject or things, that is: noun (teacher, farmer, and football), action done by those things, that is: verbs (teach, plant, and kick), and the qualities of those things, that is: adjectives (handsome, careful, strong, etc).

Example:

- I kick the ball.

$\mathrm{N}$

- They plant beautiful flowers. $\mathrm{V}$

b) Function words are those words used as a means of expressing relation of grammar/structure, such as conjunction (and, however, but), article (a, an, the), and auxiliaries (do, did, does).

Example:

- Tamzil and Ika are at home, they do not go to the beach.

\section{Conj Aux}

c) Substitute words, those represent not to the individual things or specific action, but function as substitutes for whole form classes of words. In this group, there are personal pronoun (me, you, etc), infinitive (somebody, everybody, anybody, etc), negative expression (nobody, nothing, etc), and quantity of number (each, both, etc).

Example:

- Give it to me!

- Somebody should give me advice. 
d) Distributed words, those are distributed in use according to grammatical matter as the presence of a negative. Such as: any, either, etc.

Example:

- John does not drink milk either.

\section{Importance of Learning Vocabulary}

The program of vocabulary development exposes the students not only to get many new words but also help them to get vocabulary acquisition. Vocabulary development can lead students forward, as new concepts and related words are acquired. Learning to use new words and using them in varieties ways form a dynamic process. The vocabulary knowledge is very important in four skills of English learning. All of these aspects will face the words in use. The vocabulary is very important to use in constructing the sentences and communicating. So to be able to use English, The teacher has to prepare the students to have plenty vocabularies. Vocabulary is central to language and of critical importance to the typical language learner. Lack of vocabulary knowledge will result in lack of meaningful communication. The main benefit that can be obtained from all learning strategies is autonomy; students can take charge of their own learning (Nation, 2001:222) and gain independence and self-direction. He believes that a large amount of vocabulary can be acquired with the help of vocabulary learning strategies and that the strategies proved useful for students of different language levels. Takes for example, students' will get chance and opportunity to learn by himself when the cooperative learning strategy or language learning through game are implemented in the class room. So the students' are left free without being afraid of correcting or judgment from the teacher.

\section{Games in Language Teaching}

Agoestyowaty (2007: 38) said that using of games in a learning environment will not only change the dynamic of the class, but it will also rejuvenate students and help the brain to learn more effectively. The brain is a muscle just like any other. It needs to be worked out, tested and put into competitive situations. The more exciting and interactive a teacher can make the learning environment, the more a teacher tries to introduce games and activities, the more a teacher change shapes and manipulates both the language and environment, the better the circumstance for learners. Games allow students to work co-operatively, compete with each other, strategize, think in a different way, compare and share knowledge, learn from others, learn from mistakes, work in a less stressful and more productive environment, and allow people to have fun. Games have long been advocated for assisting language learning. Here are some of the reasons why language game is useful:

1. Games add interest to what students might not find very interesting. Sustaining interest can mean sustaining effort. After all, learning a language involves long-term effort.

2. Games provide a context for meaningful communication. Even if the game involves discrete language items, such as a spelling game, meaningful communication takes place as students seek to understand how to play the game and as they communicate about the game: before, during, and after the game.

3. This meaningful communication provides the basis for comprehensible input, i.e., what students understand as they listen and read, interaction to enhance comprehensibility, e.g., asking for repetition or giving examples and comprehensible output, speaking and writing so that others can understand.

4. The emotions aroused when playing games, games also add variety to the sometimes dry, serious process of language instruction.

5. The variety and intensity that games offer may lower anxiety and encourage shyer learners to take part, especially when games are played in small groups.

6. Games can involve all the basic language skills, i.e., listening, speaking, reading, and writing, and a number of skills are often involved in the same game.

7. Games are student-centered in that students are active in playing the games, and games can often be organized such that students have the leading roles, with teachers as facilitators.

8. Many games can be played in small groups, thereby providing a venue for students to develop their skills in working with others, such as the skill of disagreeing politely and the skill of asking for help. Other advantages of games played in groups include:

a) The team aspect of many games can encourage cooperation and build team spirit.

b) Although many games involve competition, this is not necessarily the case.

c) In most games, everyone has a turn, encouraging everyone to take a turn, rather than letting others do all the talking and other actions, and discouraging one or two people from shutting out others.

9. As many games can be played outside of class, they provide a means for students to use the language outside of class time.

10. Games can connect to a variety of intelligences, e.g., 
a) Games played with others involve interpersonal intelligence

b) Games involving drawing connect with visual/spatial intelligence

c) Games often have a hands-on element, such as cards, spinners, or pieces, which connect with bodily/kines thetic intelligence

Teaching Vocabulary through Jumble Letters

Arranging Jumble Letters is a word puzzle in which a player is given a set of letters which, when arrange in the correct order. Puzzle is kind of various activities which is involved the capability in contracting and arranging the letter based on the clue, guidance, which reduces the leather anxiety, shame, stress, frightened condition during the activities.

\section{RESEARCH METHOD}

This study is conducted by using quantitative descriptive study design, which focuses on the result than the process of making test. There are two groups in experimental study, namely experimental group and control group. The experimental group is the group which is taught by using Jumble Letters, while the control group is the group which is taught without using Jumble Letters. Both of groups are given pre - test and post - test with the same items.

\begin{tabular}{|l|c|c|c|}
\hline \multicolumn{1}{|c|}{ Group } & $\begin{array}{c}\text { Pre }- \\
\text { Test }\end{array}$ & Treatment & $\begin{array}{c}\text { Post - } \\
\text { Test }\end{array}$ \\
\hline $\begin{array}{l}\text { Experimental } \\
\text { Group }\end{array}$ & $\mathrm{X}_{1}$ & $\checkmark$ & $\mathrm{X}_{2}$ \\
\hline Control Group & $\mathrm{Y}_{1}$ & - & $\mathrm{Y}_{2}$ \\
\hline
\end{tabular}

Where:

$\mathrm{X}_{1} \quad$ : Pre - Test of experimental group

$\mathrm{Y}_{1} \quad$ : Pre - Test of control group

$\mathrm{X}_{2} \quad$ : Post - Test of experimental group

$\mathrm{Y}_{2} \quad$ : Post - Test of control group

$\checkmark \quad$ : Teaching vocabulary by using Jumble Letters

: Teaching vocabulary without using Jumble Letters

\section{Sample}

The sample is the small proportion that is taken from population or analytical needing. Based on the statement it is implied that not all population is necessary involve in the study but only in the certain number of students are selected as representative.The population of this research is the students in SMP Negeri 7 Pematangsiantar and the writer takes the students in the grade VIII. It consists of ten classes. But in order to make this research efficient and practical, not all the students are investigated. Writer limits the number of the students by sampling them where the writer chooses the students in $\mathrm{VIII}_{10}$ which consists 20 students as control group and $\mathrm{VIII}_{8}$ which consists 20 students as experimental group. Total number of sample are 40 students.

\section{FINDING AND DISCUSSION}

After conducting the study and collecting the data, then the writer calculated the data, the writer found some findings. The writer divided the students in grade eight students of SMP Negeri 7 Pematangsiantar into two groups, they are experimental group (VIII - 8) and control group (VIII - 10). The test in experimental group was by using jumble letters and in control group was without using jumble letters. The students are more effective by using jumble letters technique. The writer also found the validity of experimental group is 0.81 and it is high. And the reability of the test by using $\mathrm{t}$ - test formula is 0.89 and it is very high. The mean of experimental group between pre - test and post - test is 15.25 , and the mean of control group between pre - test and post - test is 6 . It means that experimental group is more effective than control group. The result of analyzing the data, the score of $t$ - test is higher than $\mathrm{t}-$ table $(8.46>1.66)$. It means that $\mathrm{t}-$ test $>\mathrm{t}-$ table, where $\mathrm{t}-$ table is 1.66 and $\mathrm{t}$ - test is 8.46 , so $\mathrm{t}$ - test is higher than $\mathrm{t}$ - table.

\section{Discussion}

After conducting the obeservation in SMP Negeri 7 Pematangsiantar, the writer found some advantages that Jumble letters, besides it can increase the students' motivation and their vocabulary mastery, it also helps students to understand the text while reading. Using jumble letters technique in teaching and learning language is important especially in junior high school because it will not focuse on memorizing but remembering and practising. Learning vocabulary through games is an effective and interesting way that can be applied in classroom. Agoestyowaty (2007: 38) said that using of games in a learning environment will not only change the dynamic of the class, but it will also rejuvenate students and help the brain to learn more effectively. By using games in classroom, it make the fun activities, interesting, and enjoyable. So teachers can use jumble letters to help the students to increase their vocabulary in listening, speaking, reading and writing skill. Such the writer did in this thesis, the writer found out the effect of using jumble letters in teaching vocabulary in grade eight students of SMP Negeri 7 Pematangsiantar. After finishing the study, the writer found out that using jumble letters was more effective than without using jumble letters in teaching vocabulary. 


\section{V. \\ CONCLUSION}

After analyzing the data, the writer found out that jumble letters take big part in helping the students in achieving vocabulay. Students get many difficulties when they want to achieve the vocabulary, for examples they feel dificult to memorize the vocabulary and they feel bored to consult it from dictionary. So, when the researcher conducted the study, the researcher found out that the students feel more enjoyable and interested in achieving the vocabulary by using jumble letters. When the students found the questions in form of jumble letters, the students felt interested to do the questions and the students felt easy to do the questions, because jumble letters help them to remember the vocabulary. Jumble letters also helps the students in spelling the vocabulary. And from the reseach, the researcher concluded that to increase the students' vocabulary, it is better for the students to remember it than to memorize it. So, the reseacher found that jumble letters is a good technique for students to train the students memory without memorizing but remembering. In other words, jumble letters significantly affects the students' vocabulary achievement in grade eight students of SMP Negeri 7 Pematangsiantar and it can be shown from $\mathrm{t}$ - observed (8.46) is higher than $\mathrm{t}$ - table (1.66). Based on this finding, it can be concluded that the alternative hypothesis is accepted and the null hypothesis is rejected.

\section{REFERENCES}

[1] Agoestiwaty, R. (2007). Fun English Game and Activities For You. Jakarta.

[2] Allen, V.F. (1983). Techniques in Teaching Vocabulary. New York: Oxford University Press.

[3] Arikunto, S. (2006). Prosedure Penelitian. Jakarta : PT. Rineka Cipta.

[4] Arikunto,S. (2010). Prosedur Penelitian Suatu Pendekatan Praktik. Jakarta: PT Rineka Cipta.

[5] Blachowicz, C. L. Z., \& Fisher, P. (2000). Teaching vocabulary in all classrooms. Englewood Cliffs, NJ: Prentice Hall.

[6] Bruner, J. (1983). Learning to Use Language. New York: W. W Norton \& Company.

[7] Carten, J. (2007). Teaching vocabulary in lesson for classroom. Cambridge: Cambridge University Press.

[8] Creswell, John W. (2009). Research Design Qualitative, Quantitative, and Mixed Methods Approaches. California: SAGE Publications, Inc.

[9] Fries, C. C. (1975). Teaching and Learning English as Foreign Language. An Arbor: The University of Michigan Press.
[10] Fudhla, N. (2013). Enhancing Student's Vocabulary by Using Jumbled-Letter Game in English Language Teaching. Lingua Didaktika Volume 6 No 2.

[11] Hadfield, J. (1999). Intermediate vocabulary games. Harlow, Essex: Longman.

[12] Harmer, J. (1991). The Practice of English Language Teaching: New Edition. New York: Longman.

[13] Hunter, C. (2005). Games for English and Language Arts. Colorado: Cottonwood Press, Inc.

[14] Hornby, A.S. (1995). Oxford Advanced Learners' Dictionary of Current English. London: Oxford University Press.

[15] Lado, R. (1979). Language Teaching. New York: McGraw-Hill.

[16] Inc.Linse, T. (2005). Practical English Language Teaching Young Learners. New York: McGraw-Hill ESL/ELT 